\title{
Crop model validation and sensitivity to climate change scenarios
}

\author{
Mustapha El Maayar $^{1, *}$, Oliver Sonnentag ${ }^{2}$ \\ ${ }^{1}$ Department of Geography and Program in Planning, University of Toronto, 100 St. George St., Toronto, Ontario M5S 3G3, Canada \\ ${ }^{2}$ Department of Environmental Sciences, Policy and Management, Ecosystem Sciences Division, University of California, \\ Berkeley, 137 Mulford Hall \#3114, Berkeley, California 94720-3114, USA
}

\begin{abstract}
Field measurements of land surface-atmosphere heat and water exchanges, leaf area index, crop height, dry matter accumulation, and crop yield at Bondville, an agricultural site of the AmeriFlux network located in the USA Midwest, were used to evaluate the performance of the process-oriented crop model Agro-IBIS under a corn (Zea mays L.)-soybean (Glycine max (L.) Merr.) crop rotation. Simulations of drainage and nitrate/nitrogen leaching and concentration are also discussed. The simulated fertilization effect of carbon dioxide $\left(\mathrm{CO}_{2}\right)$ on corn and soybean crops was evaluated against results from a recent synthesis of Free Air- $\mathrm{CO}_{2}$ Enrichment (FACE) experiments. Two contrasting climate change projections from the Canadian Global Climate Model v.2 (CGCM2) and from the Hadley Centre coupled Model v.3 (HadCM3) were further used to assess the sensitivity of Agro-IBIS simulations of corn and soybean yields to potential climate perturbations. Overall, our results clearly show model strengths and allowed us to identify some model deficiencies. The model was able to reproduce net radiation, latent and sensible heat fluxes within 11,17 and $2 \%$ of observations, respectively. Yields of corn and soybean were underestimated on average by 11 and $10 \%$, respectively. In leaf area index, the model was able to simulate its peak within $<10 \%$ of observation, but had difficulty accurately simulating its development during the period of leaf senescence. Our results suggest that Agro-IBIS needs to be improved with regard to its simulation of the effect of rotation on corn and soybean yields, as well as its estimation of the fertilization effect of elevated atmospheric $\mathrm{CO}_{2}$ concentration on soybean yield.
\end{abstract}

KEY WORDS: Agro-IBIS · Corn-soybean rotation - Crop yield $\cdot$ Nitrate transport $\cdot \mathrm{CO}_{2}$ fertilization . Climate change

Resale or republication not permitted without written consent of the publisher

\section{INTRODUCTION}

In general, crop models have evolved during the last 4 decades from simple empirical relationships that link crop yields to climate variables, such as mean air temperature and precipitation during the growing season, into sophisticated numerical schemes that simulate plant physiology and detailed canopy and soil physics (Whisler et al. 1986, Tubiello \& Ewert 2002). Yet, some sophisticated schemes simulating crop photosynthesis were already developed in the early stages of the crop modeling era (e.g. de Wit 1965, Duncan et al. 1967). Crop models, in which the degree of complexity increases with the mechanistic description of crop growth and yield, are built for several objectives (Whisler et al. 1986). They may serve, for example, as experimental tools to investigate leaf and canopy level processes but they can also be applied for the study of crop yield responses to changes in environmental conditions over large regions. Some existing models are also able to explicitly simulate the effects of fertilization practices on water quality (e.g. Zhao et al. 2000, Wegehenkel \& Mirschel 2006). Recently, sub-components of crop models have been incorporated into global land surface schemes for the study of the potential effects of land use changes on the global carbon cycle and the Earth's climate system (e.g. Gervois et al. 2004, Matthews et al. 2004). 
The development of practices that ensure sustainable food production while minimizing potential environmental damage caused by intensified agriculture poses critical challenges for humanity (Matson et al. 1997, Cassman et al. 2002, Foley et al. 2005). To successfully meet these challenges, a thorough understanding of crop growth and development, the response of these to climate change, and, more specifically, to elevated atmospheric carbon dioxide $\left(\mathrm{CO}_{2}\right)$ concentration $\left(\mathrm{C}_{\mathrm{a}}\right)$, is of crucial importance.

To date, numerous crop models of varying complexity have been developed and applied to the investigation of potential impacts of climate change on agricultural production at local, regional, national, and global scales (Rosenzweig \& Parry 1994, El Maayar et al. 1997, Singh \& El Maayar 1998, Reilly et al. 2003, Thomson et al. 2006). At the same time, an increasing number of studies suggest that agricultural fertilization practices might have major impacts on ecosystem health (Showstack 2000, Boyer et al. 2006). Thus, crop models are being used increasingly for the establishment of sustainable agricultural management practices (Zhao et al. 2000, Donner \& Kucharik 2003). Predictions regarding future agricultural production under a changing climate are, however, still highly uncertain (Tubiello \& Ewert 2002, Long et al. 2006, Tubiello et al. 2007). One of the main reasons for the reported uncertainties of these predictions is the lack of thorough performance evaluations parallel to the on-going development of crop models. To minimize such uncertainties, Tubiello \& Ewert (2002) and Long et al. (2006) recommended continuous evaluation of crop models throughout the stages of their development using, as much as possible, long-term field data. In line with these recommendations, the goal of this study was the evaluation of the performance of Agro-IBIS (Kucharik $\&$ Brye 2003), the crop version of the Integrated BIosphere Simulator (IBIS) land surface scheme, using field data continuously collected at Bondville (Champaign County, Illinois, USA) between 1997 and 2002.

Our evaluation focuses on the performance of the model under corn (Zea mays L.)-soybean (Glycine $\max (\mathrm{L}$.) Merr.) rotation, which is the most common crop rotation practice found in Illinois (Nafziger 2003a). We evaluate: (1) the ability of the model to reproduce field measurements of energy fluxes, soil temperature and moisture, and the evolution of leaf area index (LAI), crop height, dry matter accumulation through the growing season, and crop yield; (2) simulations of water drainage and nitrate leaching and concentration (though no measurements of these variables were collected at our site); (3) the performance of Agro-IBIS using results of recent experiments on the $\mathrm{CO}_{2}$ fertilization effect on crop biomass and yield; and (4) the model's sensitivity to contrasting climatic condi- tions by evaluating the response of simulated crop yields to 2 climate change scenarios as projected by 2 climate models.

\section{METHODS}

\subsection{Model description}

Agro-IBIS is a relatively new crop model developed from IBIS (Foley et al. 1996, Kucharik et al. 2000). IBIS is a process-oriented, terrestrial ecosystem model originally developed to simulate global ecosystem dynamics, its subsequent application to agricultural ecosystems resulted in Agro-IBIS (Kucharik \& Brye 2003). Agro-IBIS simulates the effects of land use and agricultural management practices on crop yields (irrigation, crop fertilization, crop rotation), and on the transport of chemical elements such as inorganic nitrogen $(\mathrm{N})$ through leaching.

Heat, momentum, and mass exchanges within the soil-plant-atmosphere continuum are simulated at an hourly time step using the land-surface-transfer scheme (LSX) as described in detail in Pollard \& Thompson (1995). The present study uses 6 soil layers with horizon thicknesses, from top to bottom, of 0.10 , $0.15,0.25,0.50$ and $1.00 \mathrm{~m}$. The model predicts vegetation temperature, canopy air temperature and specific humidity, given the prescribed atmospheric conditions and the current soil conditions. Soil temperature and soil moisture variations within the vertical soil profile are simulated using Fick and Darcy laws, respectively. Runoff, which is partitioned into surface runoff and sub-surface runoff (drainage), is simulated according to soil physical properties (e.g. porosity, hydraulic conductivity).

Crop growth and development, and yield are simulated using a generic approach. Rather than prescribing genotype-specific parameters that are not always available for each crop species, the model relies on the physiological and phenological differences that exist among crop species to simulate crop development (Tables 1 \& 2). Leaf carbon assimilation is simulated using Farquhar et al.'s (1980) model, while models of Collatz et al. (1991) and Collatz et al. (1992) are used to simulate the coupled exchange of water and carbon at the leaf surface for $\mathrm{C}_{3}$ and $\mathrm{C}_{4}$ crops, respectively. Carbon assimilated daily by the plant is further partitioned between leaf, stem, root, and grain. The fraction of carbon that is allocated to each crop component varies according to the crop growth stage. Furthermore, the model adjusts the maximum rubisco activity $\left(V_{\max }\right)$, to account for the effect of soil water status on carbon assimilation, using a simple water stress factor (Foley et al. 1996). LAI is calculated as the product of the 
Table 1. Physiological parameters used in Agro-IBIS for soybean $\left(\mathrm{C}_{3}\right)$ and corn $\left(\mathrm{C}_{4}\right)$ crops. $V_{\max }$ : maximum rubisco activity; $\tau$ : $\mathrm{CO}_{2}$ to $\mathrm{O}_{2}$ specifity ratio; $K_{c}: \mathrm{CO}_{2}$ kinetic parameter; $K_{\mathrm{o}}$ : $\mathrm{O}_{2}$ kinetic parameter. $V_{\max }, \tau, K_{\mathrm{c}}$ and $K_{\mathrm{o}}$ are specified at $15^{\circ} \mathrm{C} . \mathrm{m}$ and $b$ are the slope and intercept of the conductance-photosynthesis relationship. $\theta$ and $\beta$ are empirical constants, governing photosynthesis colimitations. $\tau$ is the ratio of kinetic parameters describing the partitioning of enzyme activity to carboxylase or oxygenase function. Intrinsic quantum use efficiency, leaf respiration coefficient, $m, b, \theta, \beta$ and $\tau$ are dimensionless

\begin{tabular}{|lccc|}
\hline Parameters & Soybean & Corn \\
\hline Intrinsic quantum use efficiency & 0.08 & 0.05 \\
Leaf respiration coefficient & 0.015 & 0.010 \\
Stomatal conductance coefficients: & $m$ & 9.0 & 4.0 \\
& $b$ & 0.01 & 0.03 \\
Minimum stomatal conductance $\left(\mathrm{m} \mathrm{s}^{-1}\right)$ & 0.00001 & 0.00001 \\
Photosynthesis coupling coefficients: & $\theta$ & 0.95 & 0.97 \\
& $\beta$ & 0.80 & 0.80 \\
$V_{\max }\left(\mu \mathrm{mol} \mathrm{m}^{-2} \mathrm{~s}^{-1}\right)$ & 65 & 70 \\
$\tau$ & & 4500 & 4500 \\
$K_{\mathrm{c}}\left(\mathrm{mol} \mathrm{mol}^{-1}\right)$ & 0.0015 & 0.0015 \\
$K_{\mathrm{o}}\left(\mathrm{mol} \mathrm{mol}^{-1}\right)$ & 0.25 & 0.25 \\
\hline
\end{tabular}

accumulated leaf carbon and the specific leaf area. Crop height is calculated as a function of LAI using an empirical quadratic function, according to Sharpley \& Williams (1990).

Agro-IBIS simulates the effects of inorganic $\mathrm{N}$ available to plants on crop growth and yield from 4 possible sources, including atmospheric deposition, fixation, fertilizer, and soil organic matter mineralization. N mineralization is simulated according to Parton et al.

Table 2. Phenological characteristics of the simulated corn and soybean crops in Agro-IBIS along with some key growth parameters. For corn and soybean to reach physiological maturity, 2300 and 1900 degree days, respectively, were required (Nafziger, 2003b,c). GDD: growing degree days

\begin{tabular}{|c|c|c|}
\hline & Soybean & Corn \\
\hline $\begin{array}{l}\text { Base temperature }\left({ }^{\circ} \mathrm{C}\right) \text { for accumulated } \\
\text { thermal time }\left(\mathrm{GDD}_{\mathrm{T}},{ }^{\circ} \mathrm{C}^{-1}\right) \text { and growth }\end{array}$ & 10.0 & 8.0 \\
\hline Phase 1 duration: planting to emergence ( $\%$ of GDD) & $3^{\mathrm{a}}$ & $3^{\mathrm{b}}$ \\
\hline Phase 2 duration: emergence to silking ( $\%$ of GDD) & $67^{a}$ & $57^{\mathrm{b}}$ \\
\hline Phase 3 duration: grain fill to maturity ( $\%$ of GDD) & $30^{\mathrm{a}}$ & $40^{\mathrm{b}}$ \\
\hline Carbon fraction in dry matter (leaf and stem) & 0.50 & 0.50 \\
\hline Carbon fraction in grain & 0.45 & 0.45 \\
\hline Maximum leaf area index $\left(\mathrm{m}^{2} \mathrm{~m}^{-2}\right)$ & 6.0 & 5.0 \\
\hline Maximum crop height (m) & 0.75 & 2.5 \\
\hline Maximum harvest index & 0.38 & 0.60 \\
\hline Grain fraction of reproductive C pools & 0.85 & 0.85 \\
\hline Initial fraction of $\mathrm{C}$ allocation to leaf & 0.60 & 0.64 \\
\hline to stem & 0.15 & 0.16 \\
\hline to roots & 0.25 & 0.20 \\
\hline End of season fraction of $\mathrm{C}$ allocation to leaf & 0.05 & 0.05 \\
\hline to stem & 0.25 & 0.10 \\
\hline to roots & 0.25 & 0.20 \\
\hline${ }^{\mathrm{a}} \mathrm{GDD}_{10 i}{ }^{\mathrm{b}} \mathrm{GDD}_{8}$ & & \\
\hline
\end{tabular}

(1987), based on the flow of carbon and the difference of the $\mathrm{C} / \mathrm{N}$ ratio of the microbes and their efficiency versus the $\mathrm{C} / \mathrm{N}$ ratio of the material that is being decomposed. $\mathrm{N}$ outputs of the soil-plant system are partitioned between plant $\mathrm{N}$ uptake, denitrification, and $\mathrm{N}$ leaching. Agro-IBIS assumes that $\mathrm{N}$ losses via $\mathrm{N}$ denitrification correspond to a fixed fraction (0.5) of immobile $\mathrm{N}$, while $\mathrm{N}$ leaching is modelled using a convective transport sub-model that simulates the transport of $\mathrm{NO}_{3}-\mathrm{N}$ through the soil profile as a function of water fluxes (see details in Kucharik \& Brye 2003).

\subsection{Field site and data}

The Bondville AmeriFlux site is located near Champaign, IL, USA $\left(40^{\circ} 00^{\prime} \mathrm{N}, 88^{\circ} 18^{\prime} \mathrm{W}\right)$ at an altitude of 300 $\mathrm{m}$ above mean sea level. The soil is silty loam and the climate is classified as humid continental with a $30 \mathrm{yr}$ annual mean temperature of $10.8^{\circ} \mathrm{C}$ and an annual mean total precipitation of $1043 \mathrm{~mm}$ (1971-2000 climate normals). Corn (Years 1997, 1999 and 2001) and soybean (Years 1998, 2000 and 2002) were planted in rotation.

Hourly measurements, at the Bondville site, of air temperature, precipitation, relative humidity, incoming shortwave and longwave radiation, wind speed and atmospheric pressure were used to drive the AgroIBIS model between 1997 and 2002. A measurement gap in precipitation between July 13 and September 20, 2000 was filled with precipitation measurements from the same site as reported by the US Environmental Protection Agency (EPA; www.epa.gov/castnet/data.html).

Records of Alexander \& Smith (1990) for Champaign County (www.nass.usda.gov) were used to account for historical $\mathrm{N}$ applications. These records suggest that $\mathrm{N}$ fertilization increased linearly from $0 \mathrm{~kg} \mathrm{~N} \mathrm{ha}{ }^{-1}$ in 1950 to $135 \mathrm{~kg} \mathrm{~N} \mathrm{ha}^{-1}$ in 1980 for corn, and from $0 \mathrm{~kg} \mathrm{~N} \mathrm{ha}^{-1}$ in 1950 to $31 \mathrm{~kg} \mathrm{~N}$ $\mathrm{ha}^{-1}$ in 1991 for soybean. Rates of $\mathrm{N}$ fertilization remained unchanged after 1980 and 1991 for soybean and corn, respectively (see also Donner \& Kucharik 2003). The effect of atmospheric $\mathrm{N}$ deposition on crop growth is accounted for in Agro-IBIS using the empirical relationship between atmospheric $\mathrm{N}$ deposition and precipitation provided by Parton et al. (1987), but adjusted to the Bondville site based on measurements provided by the EPA (Fig. 1).

Planting dates were prescribed in 1997 (April 18), 1998 (June 1), 1999 (May 10), 
2000 (June 1), 2001 (April 19), and 2002 (June 1) according to the site's documentation, but predicted by the model prior to 1997 . When not prescribed, planting date is triggered when the $10 \mathrm{~d}$ running average mean air temperature exceeds the base temperature for accumulated thermal time $\left({ }^{\circ} \mathrm{C} \mathrm{d}^{-1}\right.$; see Table 2$)$, and when the $10 \mathrm{~d}$ running average minimum air temperature exceeds a threshold minimum temperature that is required for planting $\left(6^{\circ} \mathrm{C}\right.$ for soybean, $4^{\circ} \mathrm{C}$ for corn). Date of plant growth termination corresponds to the day when the $5 \mathrm{~d}$ running mean minimum air temperature falls below $5^{\circ} \mathrm{C}$. The soil was prescribed as siltloam ( $20 \%$ sand, $65 \%$ silt, $15 \%$ clay).

Following Kucharik et al. (2000) and Kucharik \& Brye (2003), the model was run for 250 yr prior to 1997 in order to bring soil $\mathrm{C}$ and $\mathrm{N}$ pools into equilibrium in the soil biogeochemistry sub-model. Data from the Climate Research Unit, University of East Anglia (CRU; New et al. 2000) for the $0.5^{\circ} \times 0.5^{\circ}$ grid cell that corresponds to the Bondville site were used for the equilibrium simulation. To ensure for more realistic and accurate daily weather variability in our crop simulation (see Nonhebel 1994), the CRU data were used in conjunction with the National Center for Environmental Prediction (NCEP, www.cpc.ncep.noaa.gov/) reanalysis of daily weather anomalies for the period from 1958 to 1996. Prior to 1958 , daily meteorological data were generated using the weather generator simulation model WGEN (Richardson \& Wright 1984). Since its development, WGEN has been extensively tested and validated for different climates; and discussion of its strengths, weaknesses and improvements can be found in several publications (e.g. Richardson \& Wright 1984, Williams
1995, Friend 1998, Semenov et al. 1998, Hayhoe 1998, Hayhoe 2000). Hourly meteorological data are generated by Agro-IBIS using empirical equations. Calendar, orbital, and daylength calculations needed to derive diurnal variations of solar radiation are calculated according to Campbell \& Norman (1998). Diffuse and direct components of global radiation are separated according to Spitters et al. (1986) and Friend (1998). Infrared radiation is calculated according to Idso (1981). Hourly maximum and minimum temperatures are calculated as a function (Fourier series) that fits the diurnal temperature cycle, while specific humidity is adjusted against daily minimum temperature (Campbell \& Norman 1998). Wind speed and snow and rain calculations are performed following the logic of the EPIC Model (Sharpley \& Williams 1990).

Half-hourly measurements of net radiation $\left(R_{\mathrm{n}}\right)$, latent $(\lambda E)$, sensible $(H)$, and soil heat $(G)$ fluxes, and soil temperature $\left(T_{\text {soil }}\right)$ and moisture $\left(\theta_{\text {soil }}\right)$ were available to evaluate the performance of the model. Additional measurements included dry matter accumulation, LAI, crop height and crop yield. A detailed description of all measured data and instrumentation can be found in Meyers \& Hollinger (2004) and in the FluxNet website (http://www.fluxnet.ornl.gov/fluxnet/ sitepage.cfm?SITEID=830).

\subsection{Sensitivity to climate change scenarios}

The assessment of the impacts of elevated $\mathrm{C}_{\mathrm{a}}$ and climate change on crop yields is an important field of application in crop models. In this study, the response

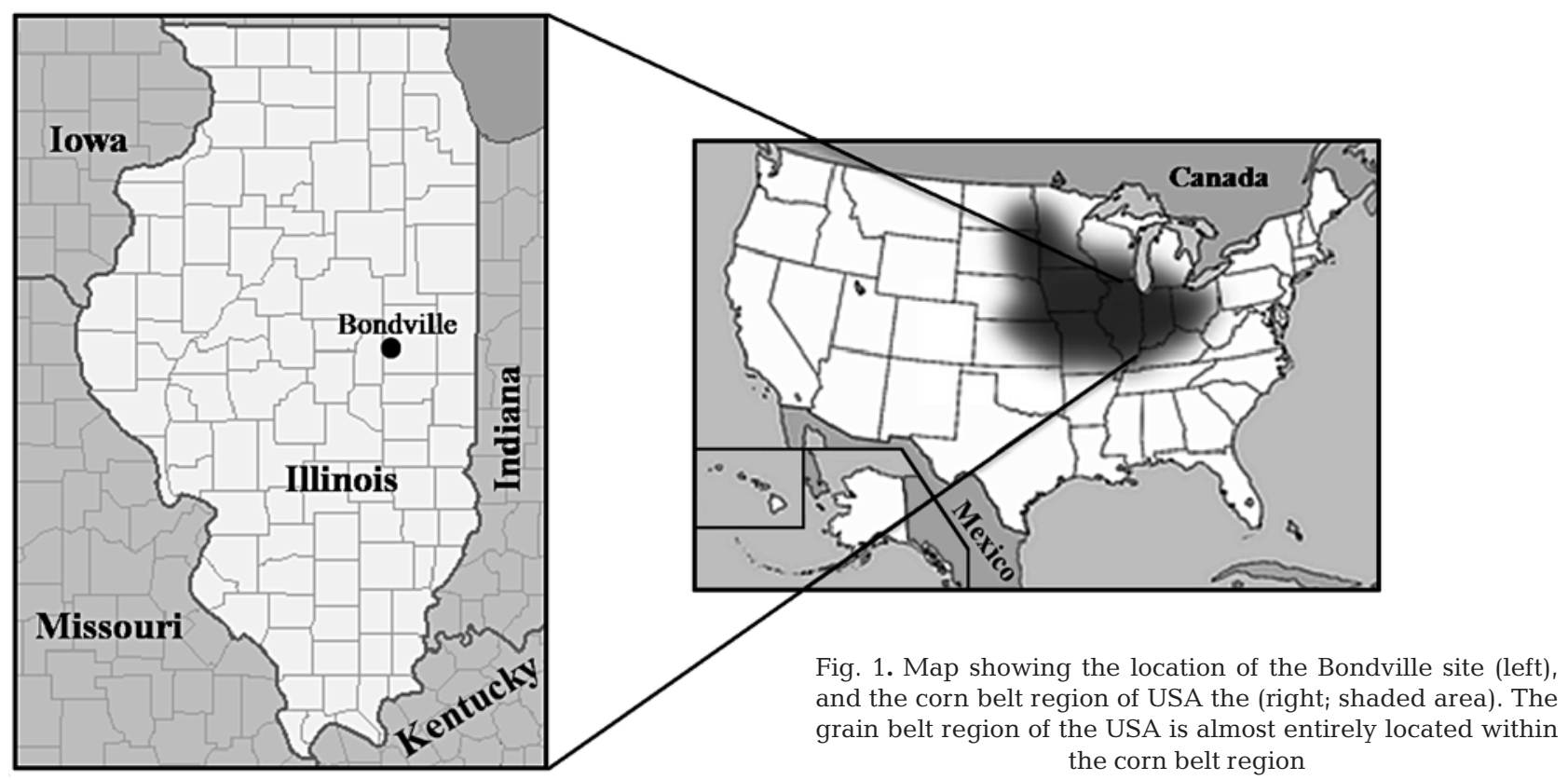


of Agro-IBIS in terms of crop yields to 2 contrasting climate change scenarios as projected by the Canadian Global Climate Model v.2 (CGCM2, Flato et al. 2000), thereafter referred to as Scenario S1; and the Hadley Center Coupled Model v.3 (HadCM3, Pope et al. 2000), thereafter referred to as Scenario S2, was investigated. S1 and S2 were obtained for a $\mathrm{C}_{\mathrm{a}}$ of $700 \mathrm{ppm}$ and are described by the Intergovernmental Panel on Climate Change (IPCC 2001) as belonging to the A1FI (very rapid economic growth with intensive fossil use) and B2 (emphasis on local solutions) families, respectively. S1 and S2 were selected from 16 available climate change scenarios (IPCC 2001, Mitchell et al. 2004) for 2 reasons: (1) S1 and S2 exhibit the highest $\left(6.3^{\circ} \mathrm{C}\right)$ and the lowest $\left(1.7^{\circ} \mathrm{C}\right)$ increase in mean annual air temperature, respectively; and (2) although average total annual precipitation increases in both scenarios (Table 3), S1 exhibits a decrease $(-29.4 \mathrm{~mm})$ and S2 an increase $(+13.2 \mathrm{~mm})$ in precipitation during the growing season (May to September). The responses of crop yields to the combined effects of climate change and increased $C_{a}$ were further investigated by performing 2 additional simulations in which prescription of each of the S1 and S2 climate scenarios and a $\mathrm{C}_{\mathrm{a}}$ of $700 \mathrm{ppm}$ were combined. In all simulations (S1, S2, $\left.\mathrm{S} 1+\mathrm{CO}_{2}, \mathrm{~S} 2+\mathrm{CO}_{2}\right)$, current annual rates of fertilizer application (i.e. $135 \mathrm{~kg} \mathrm{~N} \mathrm{ha}^{-1}$ for corn, and $31 \mathrm{~kg} \mathrm{~N}$ $\mathrm{ha}^{-1}$ for soybean; see Section 2.2) were assumed to apply under both climate change scenarios. The main objective of this part of the study was to examine the sensitivity of the model to various atmospheric forcing conditions rather than to provide an assessment of potential climate change effects on corn and soybean yields at the Bondville site.

Table 3. Change in average monthly air temperature (Temp., ${ }^{\circ} \mathrm{C}$ ) and precipitation (Prec., $\mathrm{mm}$ ) according to the S1 (CGCM2) and S2 (HadCM3) scenarios. Annual: changes in average monthly temperature and in total annual precipitation

\begin{tabular}{|lccccc|}
\hline \multirow{2}{*}{ Month } & \multicolumn{2}{c}{ CGCM2 } & & \multicolumn{2}{c|}{ HADCM3 -} \\
\cline { 2 - 3 } & Temp. & Prec. & & Temp. & Prec. \\
\hline Jan & 7.7 & 4.9 & 2.2 & 1.9 \\
Feb & 8.1 & 6.1 & 1.7 & 0.1 \\
Mar & 7.4 & 7.9 & 1.8 & 7.9 \\
Apr & 7.1 & 9.6 & 1.2 & 4.3 \\
May & 6.9 & 8.5 & 1.3 & 5.0 \\
Jun & 6.2 & -3.2 & 1.5 & 3.3 \\
Jul & 5.5 & -9.8 & 1.6 & 3.9 \\
Aug & 5.4 & -10.6 & 1.5 & 0.9 \\
Sep & 5.9 & -14.3 & 1.9 & 0.1 \\
Oct & 5.1 & 8.4 & 1.9 & 2.0 \\
Nov & 4.8 & 10 & 1.7 & 4.2 \\
Dec & 5.3 & 11.3 & 2.3 & 3.4 \\
Annual & 6.3 & 28.7 & 1.7 & 36.9 \\
\hline
\end{tabular}

\subsection{Quantification of the results}

Quantification of the simulation results were based mainly on the relative mean bias error (MBE: relative difference between simulated and observed values), the coefficient of determination $\left(r^{2}:\right.$ square of the Pearson correlation coefficient), root mean square error (RMSE), and the coefficient of variation (CV: ratio of standard deviation to the mean value) (Keller \& Warrack 1997).

\section{RESULTS AND DISCUSSION}

\subsection{Energy fluxes, crop development and yields}

Agro-IBIS simulated an average peak LAI of 5.0 for corn and 6.0 for soybean (Fig. 2a). These simulated values are within 2 and $10 \%$ of observed values of corn (5.1) and soybean (6.6), respectively. The discrepancy between measured and simulated LAI is larger during corn years $(1997,1999$ and 2001) than during soybean years $(1998,2000)$, especially during the second half of the growing season, which roughly corresponds to the period of leaf senescence (Fig. 2a). As pointed out in Section 2.1, rather than prescribing genotype-specific parameters, Agro-IBIS relies on the physiological differences that exist among crop species to simulate crop development. This might explain the discrepancy between simulated and observed LAI during the period of leaf senescence, though this point remains unclear. Other authors have pointed out the difficulty of representing leaf senescence in cropping systems (e.g. Suyker et al. 2005). Overall, $\mathrm{r}^{2}$ reached 0.86 and 0.84 for corn and soybean, respectively. The discrepancy between simulated and measured data yielded an overall RMSE of 0.90 for corn and 0.94 for soybean. Moreover, despite the limited availability of field data, the model appears to be able to simulate crop height and dry matter accumulation relatively well (Fig. 2b,c). Dry matter, however, accumulates faster in the model than in the field during the second half of the growing season, because of the overestimation of LAI during that period (Fig. 2a,c). The comparison between simulated and measured crop height values yielded an $\mathrm{r}^{2}$ of 0.59 and an RMSE of 0.17 (corn only). For dry matter accumulation, the same comparison yielded $\mathrm{r}^{2}=0.98$ and $\mathrm{RMSE}=0.19$ for corn, and $\mathrm{r}^{2}=0.92$ and RMSE $=$ 0.14 for soybean.

Daily energy budget components were reproduced fairly accurately (Fig. 3, Table 4). However, the model tends to underestimate $H$ (Fig. 3b), especially during summer (period corresponding to the highest values of $R_{\mathrm{n}}$ in Fig. 3a). As found for forest ecosystems simulated with IBIS (e.g. El Maayar et al. 2001), the underestima- 

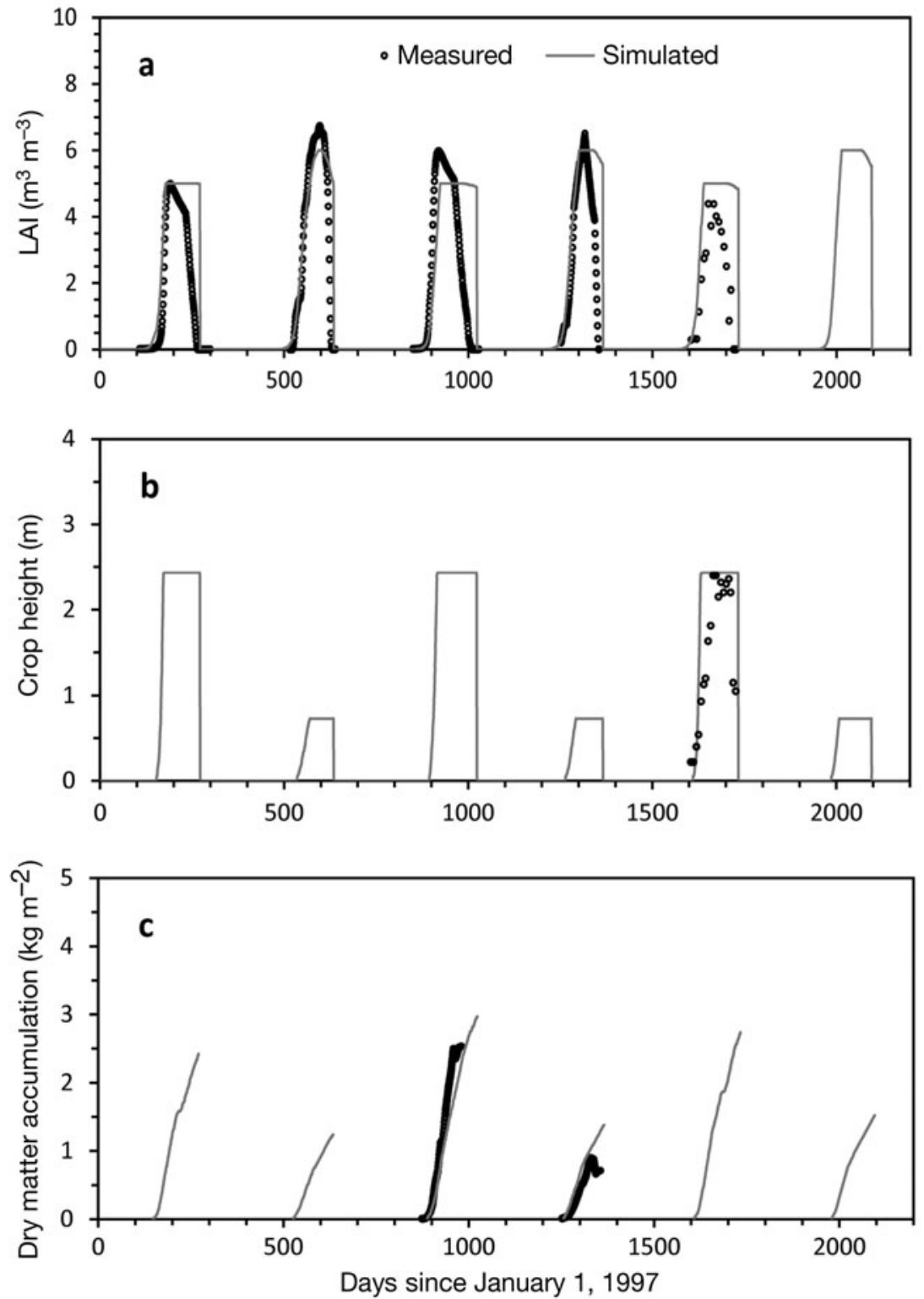

Fig. 2. Simulated and measured (a) leaf area index (LAI), (b) crop height, and (c) dry matter accumulation. Lines and dots refer to simulated and measured data, respectively

tion of $H$ is the consequence of the slight underestimation of $R_{\mathrm{n}}$ (Fig. 3a), which results from an overestimation of upwelling longwave radiation caused by a slight overestimation of soil temperature (see Fig. 4a). Over the entire period of simulation (1997-2002), MBE averaged $-11,-17$ and $-2 \%$ for $R_{n}, H$ and $\lambda E$, respectively, which lies within the acceptable range of $\pm 20 \%$ for the main components of the energy budget of vegetated surfaces (El Maayar et al. 2008). Average MBE of $G$ reached $57 \%$, but this is due to the relative difference between 2 small quantities rather than to a structural problem in the model (average simulated and measured $G$ are 0.05 and $0.03 \mathrm{MJ} \mathrm{m}^{-2} \mathrm{~d}^{-1}$, respectively; see Fig. 3d). Nevertheless, it is to be expected that the incorporation of the effect of crop residues on heat partitioning to soil would improve $G$ simulations, as several authors have demonstrated that crop residues in agro-ecosystems and mulch layers in forest ecosystems may have major effects on soil thermal and hydrologic budgets (Chung \& Horton 1987, Horton et al. 1994, Enrique et al. 1999, El Maayar et al. 2001).

In general, $T_{\text {soil }}$ is generally well simulated, even though the model tends to occasionally underestimate temperature of the 2 top layers during winter, especially in January (period that corresponds to the lowest temperature values; Fig. $4 \mathrm{a}-\mathrm{d}$ ). Such an underestimation might be the result of the inadequate representation of soil thermal conductivity during cold periods, when soil pores are partly or totally filled with ice (Nijssen et al. 2003), which would contribute to the high MBE for $G$ (Fig. 4d). Outside the cold season, the difference between simulated and measured daily $T_{\text {soil }}$ rarely exceeded $3{ }^{\circ} \mathrm{C}$ (Fig. 4a-d). Overall, the model overestimates $T_{\text {soil }}$ by $2.3,1.8,1.6$ and $1.7^{\circ} \mathrm{C}$ for the $0-10,10-25,25-50$ and $50-100 \mathrm{~cm}$ soil layers, respectively.

Agro-IBIS also captures the temporal dynamics of $\theta_{\text {soil }}$ throughout the soil profile in response to precipitation inputs (Fig. 4e-h), though the vertical diffusion of water through the soil profile, as simulated by the model, appears to be slightly faster than it actually is, which is indicated by the slight underestimation of $\theta_{\text {soil }}$ in the 15-25 cm soil layer (Fig. 4f) and the slight overestimation of $\theta_{\text {soil }}$ in the 50-100 cm layer (Fig. 4h). This resulted in both an amplification and a dampening of the seasonal variation of $\theta_{\text {soil }}$ by the model, compared to observations, for the 2 nd and 4 th soil layers, respectively (Fig. 4f,h). Indeed, CV reached 0.14 and 0.21 , respectively, for simulated and observed $\theta_{\text {soil }}$ in the 2nd soil layer, and 0.06 and 0.13, repsectively, for simulated and observed $\theta_{\text {soil }}$ in the 4 th soil layer. CV of the topsoil layer was 0.23 and 0.26 , respectively, for simulated and observed $\theta_{\text {soil }}$.

As indicated in Fig. 5, Agro-IBIS correctly captures the inter-annual variability in corn and soybean yields, despite the substantial underestimation of corn yield $(34 \%)$ in 1997. Simulated crop yields averaged $8.5 \mathrm{t} \mathrm{ha}^{-1}$ for corn and $2.6 \mathrm{t} \mathrm{ha}^{-1}$ for soybean while observed 

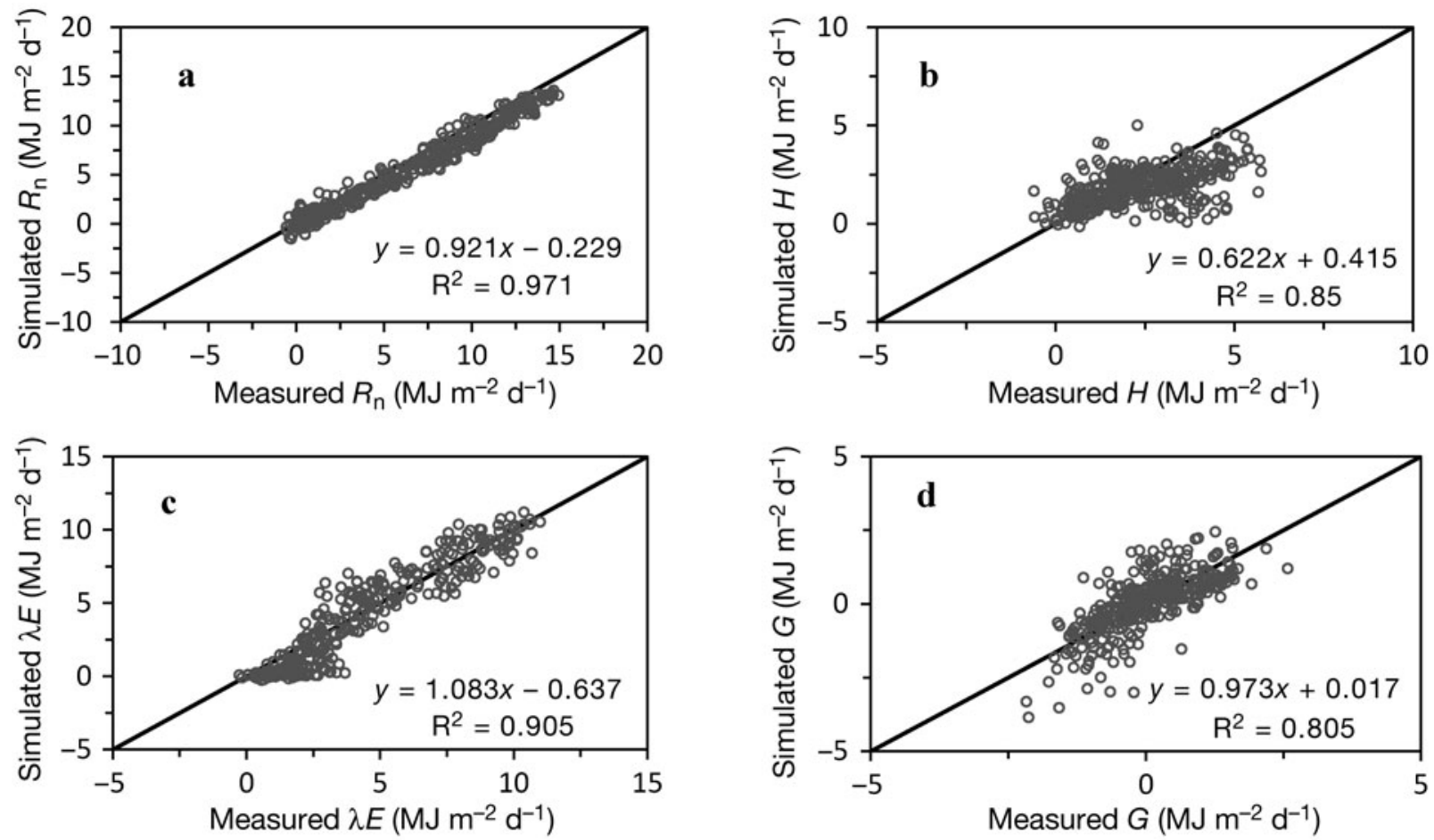

Fig. 3. Simulated vs. measured average daily energy balance components: (a) net radiation $\left(R_{\mathrm{n}}\right)$; (b) sensible heat flux $(H)$; (c) latent heat flux $(\lambda E)$; and (d) soil heat flux $(G)$

yields averaged 9.6 and $2.9 \mathrm{t} \mathrm{ha}^{-1}$ for corn and soybean, respectively. This underestimation of corn $(11 \%)$ and soybean $(10 \%)$ yields by Agro-IBIS might result from an overestimation of the simulated water stress or from an inadequate simulation of the partitioning of carbon assimilates, or a combination of both. However, a set of runs shows that Agro-IBIS underestimates the positive effect of crop rotation on corn yield, and it fails to reproduce any positive effect on soybean yield (Table 5 ; comparison with reported observations by Nafziger $[2003 b, c])$. These results are extremely important as they provide a plausible explanation concerning the overall underestimation of crop yields as described above (and shown in Fig. 5) i.e. underestimation of crop yield is at least partially due to the underestimation of the positive effect of crop rotation on crop yields. Furthermore, underestimation of the positive effect of crop rotation on crop yields might result from an overestimation of the $\mathrm{C}: \mathrm{N}$ ratio of crop residues, which causes an underestimation of $\mathrm{N}$ mineralization, and consequently an underestimation of soil $\mathrm{N}$ available for plant uptake. The simulated C:N ratio be-

Table 4. Statistics of observed and simulated average daily net radiation $\left(R_{\mathrm{n}}\right)$ and sensible, latent and soil heat fluxes $(H, \lambda E$ and $G$ respectively) and their SD. All values are given in $\mathrm{MJ} \mathrm{m}^{-2} \mathrm{~d}^{-1} \cdot \mathrm{r}^{2}$ is the coefficient of determination and MBE is the relative mean bias error

\begin{tabular}{|c|c|c|c|c|c|c|c|c|}
\hline Year & Measured & $\begin{array}{l}R_{\mathrm{n}} \\
\text { Simulated }\end{array}$ & Measured & $\begin{array}{l}H \\
\text { Simulated }\end{array}$ & Measured & $\begin{array}{l}\text { E Simulated } \\
\text { Sim }\end{array}$ & Measured & $G$ \\
\hline 1997 & 7.42 & 6.05 & 2.42 & 2.25 & 3.62 & 3.68 & 0.16 & 0.05 \\
\hline 1998 & 7.13 & 5.43 & 1.77 & 1.67 & 4.34 & 3.69 & 0.17 & 0.04 \\
\hline 1999 & 6.95 & 5.84 & 2.45 & 1.69 & 4.15 & 4.00 & 0.16 & 0.04 \\
\hline 2000 & 5.65 & 5.57 & 2.43 & 1.83 & 3.99 & 3.80 & 0.03 & -0.10 \\
\hline 2001 & 5.79 & 5.81 & 2.38 & 1.83 & 4.65 & 3.66 & -0.63 & 0.17 \\
\hline 2002 & 5.90 & 5.71 & 1.71 & 1.67 & 2.40 & 3.86 & 0.29 & 0.07 \\
\hline Corn years & 6.72 & 5.90 & 2.42 & 1.93 & 4.14 & 3.78 & -0.10 & 0.09 \\
\hline Soybean years & 6.23 & 5.57 & 1.97 & 1.72 & 3.58 & 3.79 & 0.16 & 0.01 \\
\hline Overall average & 6.47 & 5.73 & 2.19 & 1.82 & 3.86 & 3.78 & 0.03 & 0.05 \\
\hline SD & 4.47 & 4.42 & 1.40 & 1.67 & 2.98 & 3.07 & 0.79 & 1.33 \\
\hline MBE (\%) & & -11 & & -17 & & -2 & 57 & \\
\hline $\mathrm{r}^{2}$ & & 0.97 & & 0.58 & & 0.91 & & 0.81 \\
\hline
\end{tabular}



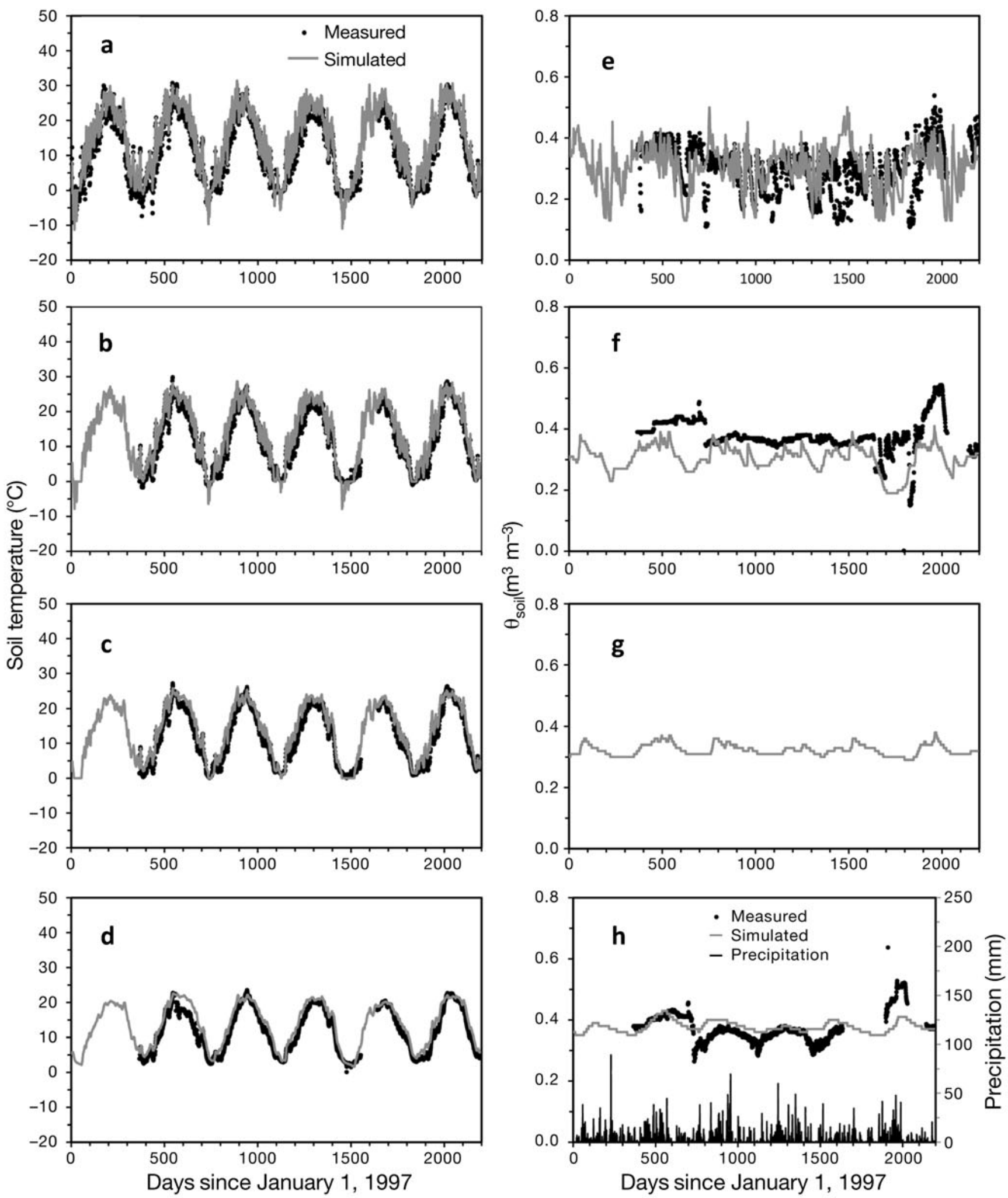

Fig. 4. Simulated and measured soil temperature and volumetric soil moisture content $\left(\theta_{\text {soil }}\right)$ at the soil layers: $(\mathrm{a}, \mathrm{e}) 0-0.10 \mathrm{~m}$; (b,f) $0.10-0.25 \mathrm{~m}_{i}(\mathrm{c}, \mathrm{g})$ 0.25-0.50 $\mathrm{m}_{i}(\mathrm{~d}, \mathrm{~h})$ 0.50-1.00 m. Daily variation of precipitation is also shown in (h). For all figures, lines and dots refer to simulated and measured data, respectively. In (a), (b), (c), and (d), soil temperature was measured at the following depths (from surface to bottom): 0.04, 0.16, 0.32, and $0.64 \mathrm{~m}$, respectively. In (e), (f), and (h), $\theta_{\text {soil }}$ was measured at the following depths (from surface to bottom): $0.05,0.20$, and $0.60 \mathrm{~m}$, respectively 


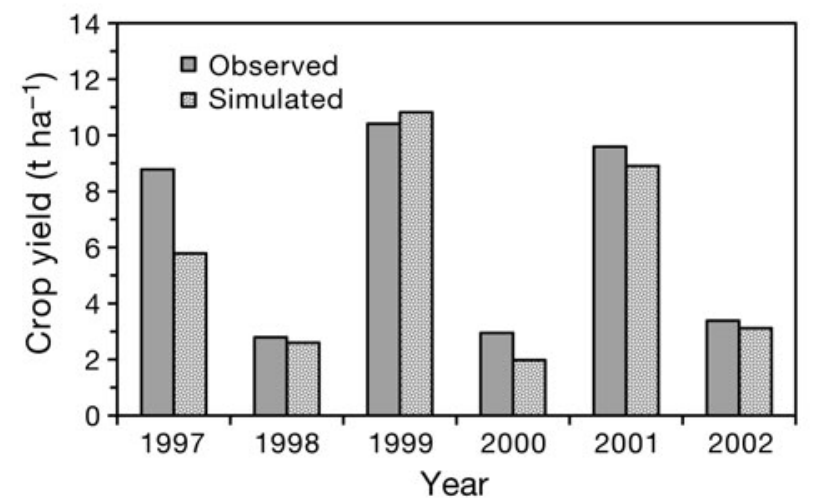

Fig. 5. Simulated and observed yields of corn (1997, 1999 and 2001) and soybean (1998 and 2000) crops. Observed yields are taken from statistics of the United States Department of Agriculture (USDA) for Champaign county

tween 1997 and 2002 averaged 94.4 for corn and 35.5 for soybean, while it has been reported that $\mathrm{C}: \mathrm{N}$ ratio generally ranges between 50 and 100 for corn and 15 and 30 for legume crop residues (Rosales et al. 2004).

\subsection{Drainage, nitrate nitrogen leaching and concen- tration}

The simulated interannual variability of drainage positively covaries with the interannual variability of precipitation (Fig. 6a), with an average value for the drainage:precipitation ratio of 0.29 , ranging between 0.22 and 0.41 for the year with the lowest (1997: $696 \mathrm{~mm}$ ) and highest (1998: $881 \mathrm{~mm}$ ) annual precipitation, respectively. Interestingly, the same average value for the drainage:precipitation ratio, 0.29, was reported for an agricultural field in Coshocton (Ohio, USA) that receives an average annual precipitation (1085 \pm $133 \mathrm{~mm}$ ) comparable to the Bondville site (1043 mm), where the soil is also classified as silty loam and where also corn and soybean were grown in rotation (Owens et al. 2000). Taking into account these strong similarities between the Bondville and Coshocton sites, our results suggest that drainage simulation by Agro-IBIS was successful, which is a critical requirement for ade-

Table 5. Effect of corn-soybean rotation on crop yields. Simulated rates: 1961-1990. For 1997-2002 the rotation had a positive effect on corn yield $(+5 \%)$ and no effect on soybean yield. Illinois values: Nafziger (2003b,c); Avg.: observed rates, states of Illinois, Indiana, Iowa, Minnesota, New York, and Wisconsin

\begin{tabular}{|lccccc|}
\hline & $\begin{array}{c}\text { Simulated yield (t ha }{ }^{-1} \text { ) } \\
\text { After corn After soybean }\end{array}$ & \multicolumn{2}{c|}{$\begin{array}{c}\text { Effect of rotation (\%) } \\
\text { Agro-IBIS }\end{array}$} & Illinois & Avg. \\
\hline Corn & 7.1 & 7.8 & +9 & +18 & +13 \\
Soybean & 2.3 & 2.3 & 0 & +15 & +11 \\
\hline
\end{tabular}
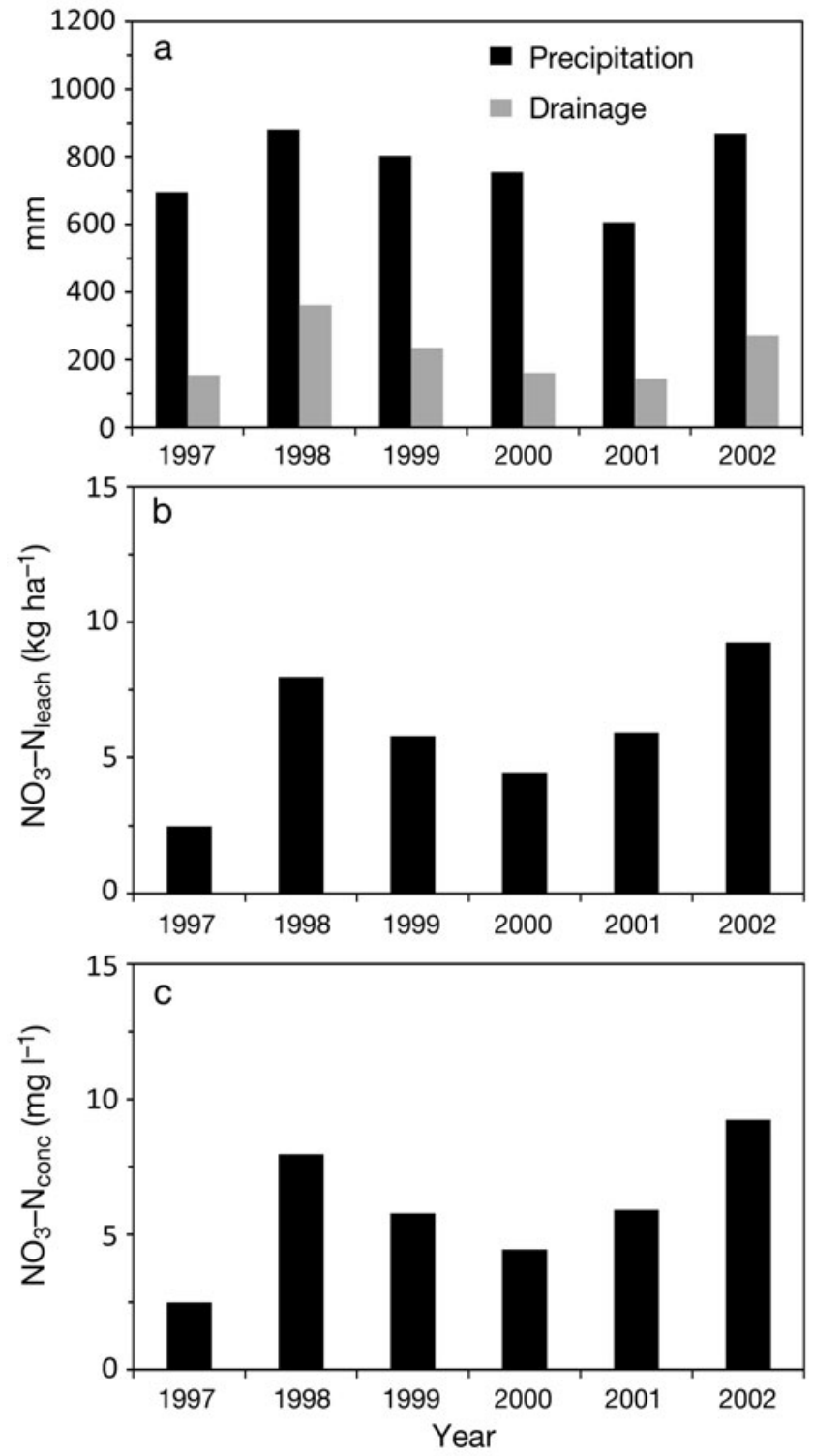

Fig. 6. (a) Simulated drainage, (b) nitrate nitrogen leaching, and (c) flow mean $\mathrm{NO}_{3}-\mathrm{N}$ concentration. Observed total annual precipitation is also shown in (a)

quate simulations of leached nitrates $\left(\mathrm{NO}_{3}-\mathrm{N}_{\text {leach }}\right)$ and flow mean $\mathrm{NO}_{3}-\mathrm{N}$ concentration $\left(\mathrm{NO}_{3}-\mathrm{N}_{\text {conc }}\right)$.

The average simulated $\mathrm{NO}_{3}-\mathrm{N}_{\text {leach }}$ and $\mathrm{NO}_{3}-\mathrm{N}_{\text {conc }}$ reached $6.0 \mathrm{~kg} \mathrm{ha}^{-1}$ and $2.8 \mathrm{mg} \mathrm{l}^{-1}$, respectively (Fig. 6b,c). In their site in Ohio (see the above paragraph), Owens et al. (2000) reported an average measured $\mathrm{NO}_{3}-\mathrm{N}_{\text {leach }}$ and $\mathrm{NO}_{3}-\mathrm{N}_{\text {conc }}$ between 1984 and 1996 of $32.8 \mathrm{~kg} \mathrm{ha}^{-1}( \pm 13.2)$ and $10.5 \mathrm{mg} \mathrm{l}^{-1}( \pm 2.5)$, respectively, following an average $\mathrm{N}$ fertilizer application of about $200 \mathrm{~kg} \mathrm{~N} \mathrm{ha}^{-1}$ during corn years and no fertilizer application during soybean years. Hence, as a simple verification of the robustness of our simulated $\mathrm{NO}_{3}-\mathrm{N}_{\text {leach }}$ and $\mathrm{NO}_{3}-\mathrm{N}_{\text {conc }}$, we conducted a numerical experiment with our model where, as in Owens et al. 
(2000), the amount of $\mathrm{N}$ fertilization was set up as 200 and $0 \mathrm{~kg} \mathrm{~N} \mathrm{ha-1}$ during corn and soybean years, respectively. In response, simulated $\mathrm{NO}_{3}-\mathrm{N}_{\text {leach }}$ and $\mathrm{NO}_{3}-\mathrm{N}_{\text {conc }}$ increased from 6.0 to $24.5 \mathrm{~kg} \mathrm{ha}^{-1}$ and from 2.8 to $10.8 \mathrm{mg} \mathrm{l}^{-1}$, respectively. Arguably, these results could be considered as extremely encouraging as the simulated $\mathrm{NO}_{3}-\mathrm{N}_{\text {leach }}$ and $\mathrm{NO}_{3}-\mathrm{N}_{\text {conc }}$ range within the uncertainty domain of the reported values of Owens et al., which were obtained under experimental conditions (soil texture, corn-soybean rotation, fertilizer application and precipitation inputs) that are very similar to our site conditions.

\subsection{Crop-yield sensitivity to $\mathrm{CO}_{2}$ and climate change scenarios}

Before exploring the combined effect of elevated $\mathrm{C}_{\mathrm{a}}$ and climate change on crop yields, we examined the response of crop yields to elevated $\mathrm{C}_{\mathrm{a}}$. As shown in Table 6, Agro-IBIS simulated a marginal beneficial effect of elevated $\mathrm{C}_{\mathrm{a}}$ from its current rate ( $\left.375 \mathrm{ppm}\right)$ to $550 \mathrm{ppm}$ on corn biomass $(4.1 \%)$ and yield (1.0\%), which closely fits experimental results (Long et al. 2006). In fact, the simulated values range within the uncertainty domain of observed values (see Fig. 2 in Long et al. 2006). The simulated response of soybean biomass to elevated $\mathrm{C}_{\mathrm{a}}$ $(+25 \%)$ also compares favorably with observations $(+32.3 \%)$. The simulated beneficial effect of elevated $\mathrm{C}_{\mathrm{a}}$ on soybean yield (4.1\%) is relatively low when compared with experimental results $(14 \%)$. This discrepancy is likely most attributable to an inadequate partitioning of assimilated carbon to different plant organs under elevated $C_{a}$, which emphasizes the need for $a$ future assessment of Agro-IBIS simulated carbon partitioning under different agricultural management practices (crop rotation, fertilized vs. unfertilized crops, irrigated vs. rainfed crops, etc.), once appropriate measurements become available.

Regarding the sensitivity of simulated crop yields to climate change, corn yields decreased by 23 and $4 \%$ and soybean by 82 and $8 \%$, under S1 and S2 scenarios, respectively (Table 7 ). These results suggest that a

Table 6. Percentage change of biomass and yield of corn and soybean crops that result from an enrichment of ambient $\mathrm{CO}_{2}$ from its current concentration $(375 \mathrm{ppm})$ to $550 \mathrm{ppm}$. Observations refer to Free-Air- $\mathrm{CO}_{2}$-Enrichment (FACE) experiment result synthesis as reported in Long et al. (2006)

\begin{tabular}{|lcccc|} 
& \multicolumn{2}{c}{ Corn } & \multicolumn{2}{c|}{ Soybean } \\
& Obs. & Sim. & Obs. & Sim. \\
\hline Biomass & 0.0 & 4.1 & 25.0 & 32.3 \\
Yield & 0.0 & 1.0 & 14.0 & 4.1 \\
\hline
\end{tabular}

Table 7. Crop yield responses (\%) to S1 and S2 climate change scenarios, and to the combination of each of the 2 scenarios with increased atmospheric $\mathrm{CO}_{2}$ concentration from its current rate to $700 \mathrm{ppm}$

\begin{tabular}{|lcrcc|}
\hline & $\mathrm{S} 1$ & $\mathrm{~S} 1+\mathrm{CO}_{2}$ & $\mathrm{~S} 2$ & $\mathrm{~S} 2+\mathrm{CO}_{2}$ \\
\hline Corn & -22.7 & -15.8 & -4.1 & -4.0 \\
Soybean & -81.8 & 13.6 & -7.9 & 53.3 \\
\hline
\end{tabular}

substantial increase in average monthly temperature during the growing season, combined with a monthly decrease in precipitation (S1), has a much stronger negative effect on simulated soybean than on corn yield, which is conceivable. It is well known that optimum growth temperature for $\mathrm{C}_{3}$ and $\mathrm{C}_{4}$ plants ranges between 15 to $20^{\circ} \mathrm{C}$ and 25 to $35^{\circ} \mathrm{C}$, respectively (Singh et al. 1998). Considering the mean air temperature fluctuation at the Bondville site within 20 to $25^{\circ} \mathrm{C}$ during an important part of the growing season and its projected increase by 5 to $6^{\circ} \mathrm{C}$ under the $\mathrm{S} 1$ scenario, corn $\left(\mathrm{C}_{4}\right)$ would benefit more than soybean $\left(\mathrm{C}_{3}\right)$. In addition to these temperature effects, the decrease in corn and soybean yields is also caused by an increase in water stress $(\sim 30 \%)$ that resulted from decreased monthly precipitation over the growing season and by decreased time to maturation (see also Singh et al. 1998, Kucharik 2003). In the S1 scenario simulation, time to maturation decreased by 37 and 50 days for corn and soybean, respectively. Under the S2 scenario, characterized by a small increase in average monthly temperature in the growing season and a small increase in monthly precipitation, the decrease in both corn $(4 \%)$ and soybean yield (8\%) was much more moderated than under the S1 scenario (Table 7). Under the S2 scenario, time to maturation decreased by less than $12 \mathrm{~d}$ for both crops. The increase of $\mathrm{C}_{\mathrm{a}}$ from $375 \mathrm{ppm}$ to $700 \mathrm{ppm}$ attenuated the negative effect of warmer conditions on corn yield, and even resulted in an increase of soybean yield (Table 7).

Regarding the sensitivity of simulated corn and soybean yields to the combined effects of elevated $C_{a}$ and climate change, our results suggest that these effects are not additive (i.e. the overall combined effect is not the sum of the individual effects). Our results also suggest that Agro-IBIS most likely underestimates soybean yield under climate change and elevated $C_{a}$ scenarios, because it underestimates the magnitude of the positive effect of $\mathrm{CO}_{2}$ fertilization on the yield of this particular crop. Overall, our results agree closely with the results of Izaurralde et al. (2003), who found, using the crop model EPIC, that corn yield increases by $4 \%$ and soybean yield decreases by $9 \%$ in the Corn Belt region of the US (a region that includes Illinois) in response to a climate change scenario that projects an 
increase of temperature and precipitation, similar to the S2 scenario used in our study. One may conclude, therefore, that both Agro-IBIS and EPIC, which is another widely used crop model, closely predict responses of corn and soybean yields to climate perturbation.

\section{CONCLUSIONS}

In this study, field measurements were used to evaluate several components of Agro-IBIS, a state-of-theart process-oriented crop model, under a crop rotation. The evaluated model components include canopy and soil physics, crop phenology, dry matter accumulation, crop yield, $\mathrm{NO}_{3}-\mathrm{N}_{\text {leach }}$ and $\mathrm{NO}_{3}-\mathrm{N}_{\text {conc }}$. Overall, our study suggests that Agro-IBIS simulations are rather consistent with observations, but potential future improvements of the model must take into consideration the following aspects:

(1) Agro-IBIS underestimates the beneficial effect of corn-soybean rotation on the yields of both crops. This underestimation is most likely due to an underestimation of soil $\mathrm{N}$ mineralization that results from an overestimation of the $\mathrm{C}: \mathrm{N}$ ratio.

(2) Though our analyses suggest a good ability of the model to simulate $\mathrm{NO}_{3}-\mathrm{N}_{\text {leach }}$ and $\mathrm{NO}_{3}-\mathrm{N}_{\text {conc }}$ under corn-soybean rotation, our conclusions are limited by the fact that no field measurements were available for the Bondville site to further rigorously evaluate our model outputs. However, we believe that Agro-IBIS would greatly benefit from the incorporation of an explicit representation of the nitrification process in its solute transport component, instead of fixing the rate of total inorganic nitrogen in $\mathrm{NO}_{3}-\mathrm{N}$ form mobile in soil solution to a constant value $(10 \%)$. Moreover, the effect of $\mathrm{N}$ volatilization on the $\mathrm{N}$ budget is not simulated within the current version of Agro-IBIS, but its incorporation might enhance the performance of the solute transport module.

(3) The magnitude of the fertilization effect of $\mathrm{CO}_{2}$ on the biomass of both corn and soybean, as well as corn yield, was captured by the model. The model, however, underestimated substantially the effect of increased $\mathrm{C}_{\mathrm{a}}$ on soybean yield, which might be explained, at least partially, by inadequate partitioning of the assimilated carbon to the different plant organs. We therefore suggest that future evaluations of the model should focus on that partitioning mechanism under different agricultural management practices (e.g. crop rotations, fertilized vs. unfertilized crops, irrigated vs. rainfed crops), once appropriate measurements become available. More generally, additional evaluations of the model under varying soil, weather and cropping system conditions would substantiate the findings of this study.
Acknowledgement. This study was initiated while M.E.M was at the Center for Sustainability and the Global Environment, University of Wisconsin, Madison. It was completed at the University of Toronto, where both authors were supported through the Fluxnet-Canada Research Network, funded by the Natural Science and Engineering Council of Canada and the Canadian Foundation of Climate and Atmospheric Sciences. We thank Dr. T. Meyers, National Oceanic and Atmospheric Administration, Atmospheric Turbulence and Diffusion Division (Oak Ridge, Tennessee, USA), for making measured data from the Bondville site available. We thank the four anonymous reviewers for their insightful and constructive comments that greatly improved this manuscript.

\section{LITERATURE CITED}

Alexander RB, Smith RA (1990) County-level estimates of nitrogen and phosphorus fertilizer use in the United States 1945 to 1985. US Geol Surv Open File Rep \# 90-130

Boyer EW, Howarth RW, Galloway JN, Dentener FJ, Green PA, Vörösmarty CJ (2006) Riverine nitrogen export from the continents to the coasts. Global Biogeochem Cycles 20:GB1S91, doi:10:1029/2005GB002537

Campbell GS, Norman JM (1998) An introduction to environmental biophysics. 2nd edn, Springer-Verlag, New York, NY

Cassman KG, Dobermann A, Walters DT (2002) Agroecosystems, nitrogen-use effeciency, and nitrogen managements. Ambio 31:132-140

Chung SO, Horton R (1987) Soil heat and water flow with a partial surface mulch. Water Resour Res 23:2175-2186

Collatz GJ, Ball JT, Grivet C, Berry JA (1991) Physiological and environmental regulation of stomatal conductance, photosynthesis and transpiration: a model that includes a laminar boundary layer. Agric For Meteorol 54:107-136

Collatz GJ, Ribas-Carbo M, Berry JA (1992) Coupled photosynthesis-stomatal conductance model for leaves of $\mathrm{C}_{4}$ plants. Aust J Plant Physiol 19:519-538

de Wit CT (1965) Photosynthesis of leaf canopies. Agric Res Rep (Wageningen) 663

Donner SD, Kucharik CJ (2003) Evaluating the impacts of land management and climate variability on crop production and nitrate export across the Upper Mississippi Basin. Global Biogeochem Cycles 17 (3), 1085, doi:10.1029/2001 GB001808

Duncan WG, Loomis RS, Williams WA, Hanau R (1967) A model for simulating photosynthesis in plant communities. Hilgardia 38:181-205

El Maayar M, Singh B, André P, Bryant C, Thouez JP (1997) The effects of climatic change and $\mathrm{CO}_{2}$ fertilisation on agriculture in Québec. Agric For Meteorol 85:193-208

El Maayar M, Price DT, Delire C, Foley J, Black TA, Bessemoulin P (2001) Validation of the Integrated Biosphere Simulator (IBIS) over Canadian deciduous and coniferous boreal forest stands. J Geophys Res 106(D13): 14339-14355

El Maayar M, Chen JM, Price DT (2008) On the use of field measurements of energy flux to evaluate land surface models. Ecol Model 214:293-304

> Enrique GS, Braud I, Thony JL, Vauclin M, Bessemoulin P, Calvet JC (1999) Modelling heat and water exchanges of fallow land covered with plant-residue mulch. Agric For Meteorol 97:151-169

Farquhar GD, von Caemmerer S, Berry JA (1980) A biogeochemical model of photosynthetic $\mathrm{CO}_{2}$ assimilation in leaves of $\mathrm{C}_{3}$ species. Planta 149:78-90 
Flato GM, Boer GJ, Lee WG, McFarlane NA, Ramsden D, Reader MC, Weaver AJ (2000) The Canadian Centre for Climate Modeling and Analysis Global Coupled Model and its climate. Clim Dyn 16:451-467

Foley JA, Prentice IC, Ramankutty N, Levis S, Pollard D, Sitch S, Haxeltine A (1996) An integrated biosphere model of land surface processes, terrestrial carbon balance, and vegetation dynamics. Global Biogeochem Cycles 10: 603-623

Foley JA, DeFries R, Asner GP, Barford C and others (2005) Global consequences of land use. Science 309:570-574

Friend AD (1998) Parameterisation of a global daily weather generator for terrestrial ecosystem and biogeochemical modelling. Ecol Model 109:121-140

Gervois S, de Noblet-Ducoudré N, Viovy N, Ciais P, Brisson N, Seguin B, Perrier A (2004) Including croplands in a global biosphere model: methodology and evaluation at specific sites. Earth Interact 8:1-25

Hayhoe HN (1998) Relationship between weather variables in observed and WXGEN generated data series. Agric Meteorol 90:203-214

Hayhoe HN (2000) Improvements of stochastic weather data generators for diverse climates. Clim Res 14:75-87

Horton R, Kluitenberg GJ, Bristow KL (1994) Surface crop residue effects on the soil surface energy balance. In: Unger PW (ed.) Managing Agricultural Residues. CRC Press, Boca Raton, FL

Idso SB (1981) A set of equations for full spectrum and 8- to $14-\mu \mathrm{m}$ and 10.5-12.5- $\mu \mathrm{m}$ thermal radiation from cloudless skies. Water Res Res, 17:295-304

IPCC (Intergovernmental Panel on Climate Change) (2001) Climate change 2001. The scientific basis. Cambridge University Press, Cambridge

Izaurralde RC, Rosenberg NJ, Brown RA, Thomson AM (2003) Integrated assessment of Hadley Center (HadCM2) climate-change impacts on agricultural productivity and irrigation water supply in the conterminous United States: Part II. Regional agricultural production in 2030 and 2095. Agric Meteorol 117:97-122

Keller G, Warrack B (1997) Statistics for management and economics, 4th edn. Duxbury Press, Pacific Grove, CA

Kucharik CJ (2003) Evaluation of a process-based agroecosystem model (Agro-IBIS) across the US cornbelt: simulations of the inter-annual variability in maize yield. Earth Interact 7:1-33

Kucharik CJ, Brye KR (2003) Integrated Biosphere Simulator (IBIS) yield and nitrate loss predictions for Wisconsin maize receiving varied amounts of nitrogen fertilizer. J Environ Qual 32:247-268

Kucharik CJ, Foley JA, Delire C, Fisher VA and others (2000) Testing the performance of a dynamic global ecosystem model: water balance, carbon balance and vegetation structure. Global Biogeochem Cycles 14:795-825

Long SP, Ainsworth EA, Leakey ADB, Nösberger J, Ort DR (2006) Food for thought: lower-than-expected crop yield stimulation with rising $\mathrm{CO}_{2}$ concentrations. Science 312: 1918-1921

Matson PA, Parton WJ, Power AG, Swift MJ (1997) Agricultural intensification and ecosystem properties. Science 277:504-509

Matthews HD, Weaver AJ, Meissner KJ, Gillet NP, Eby M (2004) Natural and anthropogenic climate change: incorporating historical land cover change, vegetation dynamics and the global carbon cycle. Clim Dyn 22:461-479

- Meyers TP, Hollinger SE (2004) An assessment of storage terms in the surface energy of maize and soybean. Agric For Meteorol 125:105-115
Mitchell TD, Carter TR, Jones PD, Hulme M, New M (2004) A comprehensive set of high-resolution grids of monthly climate for Europe and the globe: the observed record (19012000) and 16 scenarios (2001-2100). Tyndall Centre Working Paper 55, Norwich. www.tyndall.ac.uk/publications/ working_papers/wp55.pdf (Accessed 13 May 2008)

Nafziger E (2003a) Cover crops and cropping systems. Illinois Agronomy Handbook, 23rd edn, Department of Crop Science, University of Illinois at Urbana-Champaign, IL, p 54-59. http://iah.aces.uiuc.edu/index.php (Accessed 22 February 2008)

Nafziger E (2003b) Corn. Illinois agronomy handbook, 23rd edn, Department of Crop Science, University of Illinois at Urbana-Champaign, IL, p 22-34 http://iah.aces.uiuc.edu/ index.php (Accessed 22 February 2008)

Nafziger E (2003c) Soybeans. Illinois Agronomy Handbook, 23rd edn, Department of Crop Science, University of Illinois at Urbana-Champaign, IL, p 35-43 http://iah.aces. uiuc.edu/index.php (Accessed 22 February 2008)

New M, Hulme M, Jones PD (2000) Representing twentieth century space-time climate variability. II: Development of 1901-1996 monthly grids of terrestrial surface climate. J Clim 13:2217-2238

Nijssen B, Bowling LC, Lettenmaier DP, Clark D and others (2003) Simulation of high latitude hydrological processes in the Thorn-Kalix basin: PILPS Phase 2(e): 2. Comparison of model results with observations. Global Planet Change 38:31-53

> Nonhebel S (1994) The effects of use of average instead of daily weather data in crop growth simulation models. Agric Syst 44:377-396

Owens LB, Malone RW, Shipitalo MJ, Edwards WM, Bonta JV (2000) Lysimeter study of nitrate leaching from a cornsoybean rotation. J Environ Qual 29:467-474

Parton WJ, Schimel DS, Cole CV, Ojima DS (1987) Analysis of factors controlling soil organic matter levels in Great Plains grasslands. Soil Sci Soc Am J 51:1173-1179

> Pollard D, Thompson SL (1995) Use of a land-surface-transfer scheme (LSX) in a global climate model: the response to doubling stomatal resistance. Global Planet Change 10: 129-161

Pope V, Gallani ML, Rowntree PR, Stratton RA (2000) The impact of new physical parameterizations in the Hadley Centre climate model: HadAM3. Clim Dyn 16:123-146

> Reilly J, Tubiello F, McCarl B, Abler D and others (2003) US agriculture and climate change: new results. Clim Change $57: 43-69$

Richardson CW, Wright DA (1984) WGEN: A model for generating daily weather variables. USDA Agric Res Serv, Washington, DC

Rosales M, Saunders J, Sucik M (2004) Feeding the soilcarbon/nitrogen ratio. Conservation tillage fact sheet. www.akron.ars.usda.gov/fs_feedingsoil.html (Accessed 15 May 2008)

Rosenzweig C, Parry ML (1994) Potential impacts of climate change on world food supply. Nature 367:133-138

- Semenov MA, Brooks RJ, Barrow EM, Richardson CW (1998) Comparison of the WGEN and LARS-WG stochastic weather generators for diverse climates. Clim Res 10: 95-107

Sharpley AN, Williams JR (eds) (1990) EPIC-Erosion/ Productivity Impact Calculator: 1. Model documentation. US Dep Agric Tech Bull 1768

> Showstack R (2000) Nutrient over-enrichment implicated in multiple problems in US waterways. Eos Trans AGU 81: 497-499

Singh B, El Maayar M (1998) Potential impacts of GHG cli- 
mate change scenarios on sugarcane yields in Trinidad, Southern Caribbean. Trop Agric 75:348-354

Singh B, El Maayar M, André P, Bryant C, Thouez JP (1998) Potential impacts of GHG-induced climate change on agriculture: effects of acceleration of maturation, moisture stress and optimal temperature conditions. Clim Change 38:51-86

Spitters CJT, Toussaint HAJM, Goudriaan J (1986) Separating the diffuse and direct component of global radiation and its implication for modelling canopy photosynthesis Part I. Components of incoming radiation. Agric Meteorol 38:217-229

Suyker AE, Verma SB, Burba GG, Arkebauer TJ (2005) Gross primary production and ecosystem respiration of irrigated maize and irrigated soybean during a growing season. Agric Meteorol 131:180-190

Thomson AM, Izaurralde RC, Rosenberg NJ, He X (2006) Climate change impacts on agriculture and soil carbon sequestration potential in the Huang-Hai Plain of China. Agric Ecosyst Environ 114:195-209

Editorial responsibility: Mikhail Semenov,

Harpenden, UK
Tubiello FN, Ewert F (2002) Simulating the effects of elevated $\mathrm{CO}_{2}$ on crops: approaches and applications for climate change. Eur J Agron 18:57-74

Tubiello FN, Amthor JS, Boote KJ, Donatelli M and others (2007) Crop response to elevated $\mathrm{CO}_{2}$ and world food supply: a comment on 'Food for thought ...' by Long et al. Science 312:1918-1921，2006. Eur J Agron 26:215-223

Wegehenkel M, Mirschel W (2006) Crop growth, soil water and nitrogen balance simulation on three experimental field plots using the Opus model-a case study. Ecol Model 190:116-132

Whisler FD, Acock B, Baker DN, Fye RE and others (1986) Crop simulation models in agronomic systems. Adv Agron 40:141-208

Williams JR (1995). The EPIC model, 1995. In: Singh VP (ed) Computer models of watershed hydrology. Water Resources Publications, Highlands Ranch, CO, p 909-1000

Zhao SL, Gupta SC, Huggins D, Moncrief JF (2000) Predicting subsurface drainage, corn yield, and nitrate nitrogen losses with DRAINMOD-N. J Environ Qual 29:817-825

Submitted: July 23, 2008; Accepted: January 20, 2009 Proofs received from author(s): April 20, 2009 